DOI: $10.19195 / 0137-1134.119 .22$

\author{
MONIKA HACZKOWSKA
}

ORCID: 0000-0001-6502-8117

Politechnika Opolska

\title{
PREZYDIUM RADY SĄDOWNICTWA ADMINISTRACYJNEGO JAKO ORGAN SAMORZĄDU SĄDOWNICTWA ADMINISTRACYJNEGO WE WŁOSZECH
}

\begin{abstract}
Abstrakt: W systemie prawnym Republiki Włoskiej występują dwa organy samorządu sądownictwa, gwarantujące niezależność sądów i niezawisłość sędziów. Najwyższa Rada Sądownictwa stoi na straży niezależności sądownictwa powszechnego, a Prezydium Rady Sądownictwa Administracyjnego - sądownictwa administracyjnego. Mimo odmiennego składu obu organów każdy z nich zapewnia właściwą reprezentację sędziów odpowiednio sądów powszechnych i administracyjnych. Przy wyłanianiu członków realizowana jest bowiem podstawowa zasada — wyboru sędziów przez sędziów. Gwarancją samorządności sądownictwa są ponadto kompetencje Najwyższej Rady Sądownictwa oraz Prezydium Rady Sądownictwa Administracyjnego, mające fundamentalne znaczenie dla zapewnienia autonomii i niezależności sądownictwa od pozostałych władz.
\end{abstract}

Słowa kluczowe: sądownictwo administracyjne, Rada Stanu, Prezydium Rady Sądownictwa Administracyjnego, niezależność sądów, niezawisłość sędziów, samorządność sądownictwa

\section{INSTYTUCJONALNE GWARANCJE NIEZALEŻNOŚCI SĄDOWNICTWA POWSZECHNEGO WE WŁOSZECH}

Niezależność władzy sądowniczej i niezawisłość sędziów ma w tradycji konstytucyjnej Włoch ugruntowaną pozycję. Zanim uchwalona została Konstytucja Republiki Włoskiej z 27 grudnia 1947 roku$^{1}$, która w art. 104 powołała do życia Najwyższą Radę Sądownictwa (il Consiglio superiore di magistratura - CSM, NRS), tradycja ustrojowa Włoch od 1907 roku przewidywała istnienie organu gwarantującego włoskiemu sądownictwu pozycję autonomiczną i niezależną od pozostałych władz. Mimo nowelizacji ustawy zasadniczej Włoch, wynikającej między innymi z szerokiej decentralizacji władzy czy z konieczności dostosowania

${ }^{1}$ Gazzetta Ufficiale della Repubblica Italiana nr 298; dalej: G.U. Konstytucja Republiki Włoskiej weszła w życie 1 stycznia 1948 roku. 
norm konstytucyjnych w związku z członkostwem we wspólnotach europejskich, pozycja ustrojowa i kompetencje NRS się nie zmieniły. Wynika to w dużej mierze ze wspólnych wartości konstytucyjnych państw członkowskich Unii Europejskiej, w ramach których gwarancja niezależności władzy sądowniczej oraz niezawisłości sędziów jest fundamentem zasady praworządności. Jednym z elementów wartości konstytucyjnych wyrażonych w art. 2 Traktatu o Unii Europejskiej ${ }^{2}$ jest prawo każdego do sądu. Oznacza to prawo każdego do rozpoznania jego sprawy przez niezależny i niezawisły sąd w rozsądnym czasie ${ }^{3}$. Konstytucja Włoch gwarancje te zawarła w: art. 24 ust. 1, zgodnie z którym „Wszyscy mogą zwrócić się do sądu dla uzyskania ochrony własnych praw i uzasadnionych interesów”, w art. 104 ust. 1, w świetle którego „Sądownictwo stanowi system autonomiczny i niezależny od pozostałych władz”, oraz w art. 111 ust. 1 i $2^{4}$, stanowiącym, że „Każdy proces prowadzony jest na podstawie kontradyktoryjności między stronami, na warunkach równości, przed sędzią niezainteresowanym i bezstronnym”. Sam proces sądowy w świetle ustawy zasadniczej winien mieć charakter sprawiedliwy oraz trwać uzasadniony czas. Instytucją gwarantującą należytą ochronę praw człowieka w zakresie realizacji jego prawa do niezależnego i bezstronnego sądu jest NRS.

\section{SĄDOWNICTWO ADMINISTRACYJNE}

W strukturze sądownictwa Republiki Włoskiej szczególne miejsce zajmuje sądownictwo administracyjne, o którym mowa w art. 103 ust. 1 Konstytucji włoskiej, tworzone przez regionalne trybunały administracyjne (tribunali amministrativi regionali — TAR), Regionalny Trybunał Administracyjny dla Trydentu i Górnej Adygi (il Tribunale regionale di giustizia amministrativa del Trentino-Alto Adige - TRGA), działające jako organy I instancji, oraz Radę Stanu (Consiglio di Stato), będącą z jednej strony organem pomocniczym rządu w zakresie doradztwa prawno-administracyjnego i ochrony sprawiedliwości w działaniu administracji (art. 100 ust. 1), z drugiej zaś organem sądownictwa administracyjnego II instancji wobec orzeczeń TAR. Rada Stanu ma ponadto jeszcze jedną istotną i wyłączną kompetencję sądową w sprawach odwołań przeciwko aktom państwa dotyczącym regionu Sycylii, które nie należą do właściwości TAR Sycylii ${ }^{5}$. Region Sycylii

2 Traktat o Unii Europejskiej z 7 lutego 1992 roku (Dz. Urz. UE wersja skonsolidowana, Dz. Urz. UE seria C z 2012 r. Nr 326, s. 1); dalej: TUE.

3 Sposób rozumienia tej zasady został ugruntowany w orzecznictwie głównie Europejskiego Trybunału Praw Człowieka, ale także Trybunału Sprawiedliwości Unii Europejskiej.

${ }^{4}$ Zmiana art. 111 Konstytucji Republiki Włoskiej przez dodanie ust. 1-5 nastąpiła na mocy art. 1 ustawy konstytucyjnej z 23 listopada 1999 roku (G.U. z 23 grudnia 1999 r. Nr 300).

5 Z. Witkowski, System konstytucyjny Włoch, Warszawa 2000, s. 74. 
ma bowiem szczególną autonomię w sferze administracyjnej i ustawodawczej6. Wyrazem tego jest między innymi istnienie specjalnego organu, jakim jest Rada Sądownictwa Administracyjnego (RSA, inaczej: il Consiglio di Giustizia amministrativa per la Regione siciliana - CGA), pełniąca na Sycylii funkcje Rady Stanu, o której mowa w art. 100 ust. 1 i art. 103 ust. 1 Konstytucji Włoch, na mocy dekretu z 24 grudnia 2003 roku$^{7}$.

Rada Stanu (Consiglio di Stato) składa się z Przewodniczącego Rady Stanu, zastępcy Przewodniczącego Rady Stanu, przewodniczących Sekcji i Radnych Stanu. Przewodniczący Rady Stanu jest powoływany dekretem Prezydenta Republiki Włoskiej na wniosek Prezesa Rady Ministrów po wysłuchaniu Prezydium Rady Sądownictwa Administracyjnego ${ }^{8}$. Organami wewnętrznymi Rady Stanu są poza Przewodniczącym ${ }^{9}$ — jego zastępca, Prezydium Rady Sądownictwa Administracyjnego, sekretarz generalny, Zgromadzenie Ogólne sędziów (z głosem doradczym) oraz Posiedzenie Plenarne, w którym bierze udział 12 sędziów realizujących funkcje sądowe. Rada Stanu składa się z sześciu izb (sekcji), z których izby I-III mają charakter doradczy, a IV-VI pełnią funkcje sądowe.

Sądownictwo administracyjne ma długą tradycję w systemie prawa włoskiego, sięgającą jeszcze XIX wieku. Narodziło się wraz z utworzeniem IV Sekcji Jurysdykcyjnej w Radzie Stanu, na mocy ustawy z 31 marca 1889 roku ${ }^{10}$. Obecna struktura jest wynikiem długiego procesu ewolucji, którego celem była ochrona obywateli przed działaniem administracji publicznej. Początkowo ochrona ta realizowana była w ramach zwykłego postępowania sądowego przed sędzią sądu

${ }^{6}$ Konstytucja Włoch przewiduje w art. 5, że Włochy są państwem jednolitym i niepodzielnym. Uznaje przy tym istnienie szerokiej autonomii lokalnej oraz decentralizacji administracji. Konstytucja przewiduje istnienie gmin, prowincji, miast metropolitalnych oraz regionów. Obecnie istnieje 20 regionów, przy czym 5 regionów dysponuje autonomią specjalną (Friuli-Wenecja Julijska, Sardynia, Sycylia, Trydent-Górna Adyga oraz Valle d'Aosta), a pozostałych 15 ma autonomię zwykłą. Region Sycylii ma specjalną autonomię zagwarantowaną ustawą konstytucyjną z 26 lutego 1948 roku nr 2 dotyczącą przekształcenia Statutu Regionu Sycylii w ustawę konstytucyjną.

7 Rozporządzenie wykonawcze z 24 grudnia 2003 roku nr 373 stanowiące przepisy wykonawcze do specjalnego statutu regionu Sycylii w zakresie wykonywania funkcji Rady Stanu (G.U. z 14 stycznia 2004 r. Nr 10). Odmienny charakter RSA dla regionu Sycylii w strukturze sądownictwa administracyjnego we Włoszech wynika z posiadania szczególnych kompetencji, które określone zostały między innymi w Statucie specjalnym z 1946 roku, przewidującym istnienie własnych organów w zakresie sądownictwa administracyjnego i finansowego. Statut specjalny dla regionu Sycylii z 15 maja 1946 roku nr 455 na mocy ustawy konstytucyjnej z 26 lutego 1948 roku nr 2 został przekształcony w ustawę konstytucyjną. Nadało mu to wyższą rangę w systemie źródeł prawa włoskiego. Nowelizowany następnie ustawą konstytucyjną z 23 lutego 1972 roku nr 1, ustawą z 12 kwietnia 1989 roku nr 3 oraz ustawą z 31 stycznia 2001 roku nr 2.

${ }^{8}$ Il Consiglio di presidenza della giustizia amministrativa; dalej: PRSA lub Rada.

9 Funkcję przewodniczącego Rady Stanu pełni obecnie Filippo Patroni Griffi, nominowany przez Prezydenta Republiki Włoskiej 25 września 2018 roku.

${ }^{10}$ Ustawa z 31 marca 1889 roku nr 5992 dotycząca reorganizacji Rady Stanu (G.U. z 1 kwietnia 1889 r. Nr 78). 
powszechnego ${ }^{11}$. Po zjednoczeniu Włoch, które miało miejsce w marcu 1861 roku, uchwalona została ustawa z 20 marca 1865 roku (nr 2248), której art. 1 ust. 1 sekcja E głosił, że:

Specjalne sądy, pod jurysdykcją których znajdowały się dotąd spory administracyjne, zarówno w sprawach cywilnych, jak i karnych, zostały zniesione, a skargi wnoszone do nich na podstawie różnych przepisów obowiązujących będą odtąd podlegały jurysdykcji sądów powszechnych lub organowi administracyjnemu, zgodnie z zasadami określonymi w tej ustawie.

Oznaczało to, że spory o prawa obywatelskie i polityczne (to jest o wszystkie prawa podmiotowe), nawet jeśli dotyczyły administracji publicznej, zostały przekazane zwykłemu sądownictwu. W ten sposób każde zdarzenie, które spowodowało naruszenie sfery prawnej obywatela przez działanie lub zaniechanie administracji publicznej niezgodne z prawem, zostało przywrócone do jurysdykcji sądów powszechnych (zwykłych). Natomiast wszystkie inne sprawy (administracyjne), które nie wiązały się z naruszeniem praw obywateli, pozostały bez ochrony sądowej i zostały przekazane do właściwości administracji publicznej w trybie procedury odwoławczej. Spory o właściwość pomiędzy sędzią zwykłym (sądu powszechnego) a administracją publiczną, do czasu uchwalenia ustawy z $1877 \mathrm{roku}^{12}$, pozostawały w gestii Rady Stanu (organu składającego się wówczas z trzech sekcji i pełniącego jedynie funkcję doradczą). Dopiero uchwalenie ustawy z dnia 31 marca 1889 roku (nr 5992), na mocy której Rada Stanu została zreorganizowana, ponownie wprowadzono dualistyczny system sądownictwa administracyjnego we Włoszech. Stało się tak za sprawą rozbudowania wewnętrznej struktury Rady Stanu i dodania do istniejących trzech sekcji (izb) o charakterze doradczym sekcji IV o charakterze jurysdykcyjnym. Pozwoliło to na podział spraw dotyczących sporów administracyjnych na te przypisane do właściwości zwykłego sądu powszechnego i te przypisane do IV Sekcji Rady Stanu (sądowniczej). Mimo określenia w ustawie z 1889 roku właściwości IV sekcji Rady Stanu pojawiły się wątpliwości co do jej charakteru prawnego - czy jest ona organem administracji, czy też sądem administracyjnym sensu stricte. Dopiero ustawa z 7 marca 1907 roku nr $62^{13}$ „usankcjonowała” status czwartej sekcji jako organu sądowego, ustanawiając jednocześnie V sekcję w Radzie Stanu, której przyznano właściwość do merytorycznego orzekania w sporach administracyjnych ${ }^{14}$. Rozróżnienie i podział właściwości między sekcję

11 Więcej na ten temat zob. A. Angeletti, Le origini del sistema di giustizia amministrativa, [w:] Il nuovo processo amministrativo, red. R. Caranta, Bologna 2011, s. 1; F. Caringella, L'evoluzione e i principia, [w:] Manuale di diritto processuale amministrativo, red. A. Cacciari, R. Cauteruccio, Roma 2009, s. 3.

12 Ustawa z dnia 31 marca 1877 roku nr 3761, na mocy której kompetencje w zakresie rozstrzygania sporów o właściwość przeniesione zostały do Sądu Kasacyjnego w Rzymie. Szerzej zob. Manuale di giustizia amministrativa (Seconda edizione), Roma 2013, s. 4 n.

13 Ustawa z 7 marca 1907 roku nr 62 (G.U. z 15 marca 1907 r. Nr 63).

$14 \mathrm{~W}$ przeciwieństwie do właściwości sekcji IV, która ograniczona była jedynie do stwierdzania legalności aktów administracji publicznej i orzekania kasatoryjnego. 
IV i V zostały zniesione na mocy ustawy z 30 grudnia 1923 roku nr 2840 15 , która wprowadziła jednocześnie kompleksową ochronę prawną obywateli, bez względu na to, czy działaniem administracji publicznej zostały naruszone ich prawa podmiotowe, czy jedynie uzasadnione interesy.

Struktura wewnętrzna Rady Stanu w zakresie podziału na sześć izb — trzech doradczo-konsultacyjnych i trzech sądowniczych — została ostatecznie ukształtowana na mocy dekretu ustawodawczego z 5 maja 1948 roku nr 642 ${ }^{16}$, który ustanowił sekcję VI, nadając jej — jak dwóm poprzednim — funkcje sądownicze. Dopiero jednak wraz z uchwaleniem ustawy z dnia 6 grudnia 1971 roku nr $1034^{17}$, na mocy której utworzone zostały regionalne trybunały administracyjne, Rada Stanu stała się organem sądownictwa administracyjnego orzekającym w drugiej instancji od orzeczeń TAR. Dzisiaj łączy w sobie dwie funkcje — instytucji doradczo-konsultacyjnej rządu i organów administracji publicznej (głównie regionów) oraz organu sądownictwa administracyjnego. Kolejnym etapem kształtowania się sądownictwa administracyjnego było ustanowienie PRSA, organu zbliżonego w swoich kompetencjach do NRS, którego zadaniem było stanie na straży niezależności sądownictwa administracyjnego.

\section{PREZYDIUM RADY SĄDOWNICTWA ADMINISTRACYJNEGO}

\subsection{SKŁAD RADY}

Organem gwarantującym samorządność sądownictwa administracyjnego (jako sądownictwa szczególnego) jest Prezydium Rady Sądownictwa Administracyjnego. Rada została powołana ustawą z 27 kwietnia 1982 roku nr $186^{18}$ na wzór NRS dla sądów powszechnych. Zgodnie z art. 7 podstawowy piętnastoosobowy skład Rady tworzą:

- przewodniczący Rady Stanu, który przewodniczy PRSA;

- czterech stałych członków wybieranych spośród sędziów Rady Stanu;

— sześciu stałych członków wybieranych przez sędziów zasiadających w terenowych sądach administracyjnych (TAR);

15 Tekst jedn. z 26 czerwca 1924 roku nr 1054 (G.U. z 7 lipca 1924 r. Nr 158).

16 Decreto legislativo z 5 maja 1948 roku nr 642 regulujący środki mające na celu przyspieszenie wyroków w sekcjach sądowych Rady Stanu (G.U. z 11 czerwca 1948 r. Nr 134).

17 Ustawa z dnia 6 grudnia 1971 roku nr 1034 o utworzeniu regionalnych sądów administracyjnych (G.U. z 13 grudnia 1971 r. Nr 314).

18 Ordinamento della giurisdizione amministrativa e del personale di segreteria ed ausiliario del Consiglio di Stato e dei tribunali amministrativi regionali (G.U. z 29 kwietnia 1982 r Nr 117); dalej: ustawa lub ustawa nr 186. Rozdział III ustawy określającej ustrój sądownictwa administracyjnego poświęcony jest Radzie Sądownictwa Administracyjnego. 
— czterech członków, z których dwóch wybieranych jest przez Izbę Deputowanych i dwóch przez Senat większością absolutną spośród uniwersyteckich profesorów zwyczajnych prawa lub adwokatów z dwudziestoletnią praktyką zawodową.

Dodatkowo w skład Rady wchodzi czterech zastępców: dwóch zastępców wybieranych spośród sędziów Rady Stanu oraz dwóch wybieranych przez TAR. Członkowie elekcyjni wyłonieni zarówno przez obie izby parlamentu, jak i sędziów Rady Stanu oraz sędziów TAR (razem 14 członków) wybierani są na czteroletnią kadencję, bez możliwości bezpośredniej reelekcji. Oznacza to, że istnieje możliwość ponownego wyboru do składu Rady, jednakże nie może on nastąpić bezpośrednio po zakończonej kadencji.

Przejawem szczególnej pozycji ustrojowej PRSA jest zagwarantowanie prawa wyboru jej wewnętrznych organów. Po ukonstytuowaniu się składu Rady wybiera ona wiceprzewodniczącego PRSA spośród czterech członków wyłonionych przez parlament. Wybór z grona określonych członków jest jedyną materialnoprawną przesłanką wyboru na stanowisko przewodniczącego Rady.

W wyniku nowelizacji ustawy $\mathrm{nr} 186$ dokonanej ustawą z dnia 21 lipca 2000 roku ${ }^{19}$ doprecyzowane zostały zasady funkcjonowania zastępców członków wybieranych spośród sędziów Rady Stanu, o których mowa w art. 7 ust. 1 lit. B, oraz zastępców członków wybieranych spośród sędziów TAR, o których mowa w art. 7 ust. 1 lit. c). Zastępcy biorą udział w posiedzeniach Rady w wypadku nieobecności lub niemożności uczestniczenia przez członków tworzących trzon PRSA z powodu przejściowych trudności. Nie są oni zatem członkami stałymi. Podczas posiedzeń Rady mają oni prawo do zabierania głosu. Ich udział może ponadto przyczynić się do zapewnienia wymaganego kworum, natomiast w wypadkach przewidzianych w regulaminie wewnętrznym Rady mają prawo do głosowania.

Artykuł 7 ustawy w ust. 7 reguluje sytuację zastępstwa Przewodniczącego PRSA w razie jego nieobecności bądź z powodu innych przejściowych trudności uniemożliwiających mu sprawowanie funkcji. Obowiązki Przewodniczącego PRSA pełni wówczas wiceprzewodniczący, wybrany spośród czterech członków wyłonionych przez obie izby Parlamentu Republiki Włoskiej.

W świetle znowelizowanego ustawą nr 205 art. 7 ust. 4 w razie rezygnacji z członkostwa w PRSA lub utraty kwalifikacji wymaganych do zasiadania w Radzie, w czasie trwania czteroletniej kadencji, członkowie elekcyjni (wybierani) na czas pozostały do końca kadencji zostaną zastąpieni przez sędziów należących do grupy, która podczas wyborów uzyskała największą liczbę głosów. Podobna sytuacja ma miejsce, jeśli sędzia — członek PRSA — z jakiegokolwiek powodu zaprzestanie służby sędziowskiej bądź przejdzie z Rady Stanu do TAR lub odwrotnie. Przepis ten stanowi gwarancję właściwej reprezentacji członków zasiadających w PRSA, pochodzących z poszczególnych grup wyborczych. Zapobiega sytuacji,

19 Ustawa z 21 lipca 2000 roku nr 205 - Disposizioni in materia di giustizia amministrativa (G.U. z 26 lipca 2000 r. Nr 173); dalej: ustawa nr 205. 
w której w składzie PRSA znaleźliby się przedstawiciele tylko Rady Stanu bądź przedstawiciele jedynie regionalnych trybunałów administracyjnych (TAR) czy członkowie wyłaniani przez obie izby parlamentu.

Ustawodawca włoski, nadając Radzie kompetencje związane z gwarancyjną funkcją ochrony niezależności sądów administracyjnych i niezawisłości sędziów, wprowadził również mechanizm chroniący niezależność PRSA. W świetle przepisów regulujących zasady jej działania skład PRSA ma charakter mieszany, to jest łączy przedstawicieli środowiska sędziowskiego (z obligatoryjnym udziałem sześciu członków TAR oraz czterech sędziów Rady Stanu z izb IV-VI), przedstawicieli władzy wykonawczej (Przewodniczący Rady Stanu) oraz przedstawicieli wyłonionych przez władzę ustawodawczą (dwóch członków wybieranych przez Izbę Deputowanych i dwóch przez Senat). Ustawa nr 186 wprowadziła reguły dotyczące składu Rady, określiła kadencję jej członków oraz sposób ich powoływania i wybierania. Ponadto nadała w składzie Rady przewagę sędziom TAR pochodzącym z wyboru, co decyduje o niezależności tego organu. Procedura wyborcza, określona w ustawie nr 186, realizuje więc zasadę wyboru sędziów przez sędziów.

Członkiem Rady jest także, z woli ustawodawcy, Przewodniczący Rady Stanu powoływany dekretem Prezydenta Republiki Włoskiej na wniosek Prezesa Rady Ministrów po wysłuchaniu PRSA. Jest to osoba, która pełni swoje funkcje w PRSA bez oznaczania okresu kadencji i może być odwołana w każdym czasie. Członkostwo w Radzie osoby powołanej przez Prezydenta Republiki Włoskiej świadczy o szczególnej roli głowy państwa wobec władzy sądowniczej, podobnie jak sposób nominacji sędziego sądownictwa administracyjnego, która następuje na mocy dekretu Prezydenta Republiki Włoskiej na wniosek Prezesa Rady Ministrów, po rozpatrzeniu przez Radę Ministrów opinii PRSA ${ }^{20}$.

\subsection{ZASADA INCOMPATIBILITAS}

Członkostwa w PRSA — podobnie jak w NRS — nie można łączyć z mandatem parlamentarnym, jakąkolwiek funkcją w rządzie czy radzie regionalnej ${ }^{21}$ (zasada incompatibilitas). Ponadto członkowie PRSA wybierani przez Izbę Deputowanych i Senat, o których mowa w art. 18 ust. 1 lit. d ustawy nr 186, nie mogą angażować się w działalność, która mogłaby ingerować w funkcje Rady Stanu i regionalnych trybunałów administracyjnych. Złamanie tych zasad przez człon-

$20 \mathrm{~W}$ wypadku autonomii prowincji Bolzano nominacja odbywa się dodatkowo za zgodą Rady Prowincjonalnej Bolzano. Należy podkreślić, że oprócz prowincji Bolzano drugą prowincją mającą autonomię absolutną (w tym legislacyjną) w ramach autonomii specjalnej regionu Trydent i Górnej Adygi jest prowincja Trento. Nie ma ona jednak tożsamych uprawnień w zakresie wyrażania zgody na nominację sędziego sądownictwa administracyjnego przez Radę Prowincjonalną.

${ }^{21}$ Rada regionalna pełni w regionach funkcję parlamentu. 
ków PRSA może skutkować pociągnięciem ich do odpowiedzialności odszkodowawczej22.

Zasady dotyczące obowiązku wyłączenia się członków PRSA od uczestnictwa w różnych organizacjach reguluje ponadto Kodeks etyki członków PRSA, uchwalony 16 kwietnia 2010 roku $^{23}$. W punkcie 3 Kodeksu etyki jest mowa między innymi o niemożności uczestniczenia oraz przynależności przez członków PRSA do stowarzyszeń lub innych organizacji różnego rodzaju, jeżeli warunkiem przystąpienia jest złożenie przysięgi lub zobowiązania do posłuszeństwa wobec tych organizacji albo w wypadku gdy uczestnictwo w takiej organizacji może mieć wpływ na działalność sędziego jako członka PRSA. Wreszcie członkowie PRSA nie mogą uczestniczyć w podejmowaniu uchwał organów władz stowarzyszeń reprezentujących sędziów administracyjnych w sprawach dotyczących kompetencji Rady. Obowiązek wyłączenia się od uczestniczenia w różnych gremiach ma zagwarantować niezależność Rady i niezawisłość jej członków od jakichkolwiek wpływów z zewnątrz. Kodeks etyki w pkt 4 określa ponadto wyraźne zasady, jakimi zobowiązany jest kierować się członek Rady podczas sprawowania swoich funkcji. Zgodnie $\mathrm{z}$ nimi wykonuje swoje zadania $\mathrm{w}$ duchu autonomii i niezależności, przestrzegając reguły moralne i zachowując bezstronność. Zobowiązany jest zachować poufność w sprawach będących przedmiotem posiedzeń komisji wewnętrznych Rady oraz niepublicznych posiedzeń Rady. Wyrażając natomiast swoje opinie odnoszące się do działalności Rady, zobowiązany jest do zachowania najwyższej poprawności, zarówno odnośnie do treści, jak i tonu wypowiedzi.

\subsection{KOMPETENCJE RADY}

Podobnie jak w wypadku NRS — PRSA jest organem samorządu sędziów sądów administracyjnych, to jest TAR, Rady Stanu, Rady Sądownictwa Administracyjnego dla regionu Sycylii i całego sądownictwa administracyjnego, co odzwierciedla przede wszystkim jej skład zapewniający reprezentację sędziów tych sądów.

O charakterze Rady świadczą również jej kompetencje, wyrażone w art. 13 ustawy z 1982 roku (nr 186), które można podzielić na dwie grupy. Pierwsza koncentruje się wokół sposobu organizacji i zasad działania PRSA oraz regionalnych trybunałów administracyjnych. Druga grupa wiąże się natomiast z podejmowaniem uchwał w sprawach określonych w ustawie i dotyczy przede wszystkim statusu sędziów sądów administracyjnych.

${ }^{22}$ W tym zakresie art. 7 ust. 5 ustawy nr 186 po nowelizacji odsyła do art. 12 ustawy z dnia 13 kwietnia 1988 roku nr 117 — o odszkodowaniu za szkody wyrządzone podczas wykonywania funkcji sądowych i odpowiedzialności cywilnej sędziów pokoju (G.U. z 15 kwietnia 1988 r. Nr 88).

${ }^{23}$ Uchwała z 16 kwietnia 2010 roku — Kodeks etyki członków Rady Sądownictwa Administracyjnego, https://www.giustizia-amministrativa.it/documents/20142/0/nsiga_4395216.pdf/320137918eef-4519-a954-e3ac243f76e3 (dostęp: 25.02.2019). 
Do pierwszej grupy kompetencji zalicza się:

- wstępne weryfikowanie kwalifikacji członków PRSA wybranych przez sędziów i decydowanie o ewentualnych skargach wniesionych w związku z ich wyborem;

— określanie zasad działania PRSA poprzez uchwalenie jej regulaminu wewnętrznego;

— formułowanie wniosków dotyczących sposobu organizacji oraz zmian w zakresie funkcjonowania TAR po wysłuchaniu przewodniczących regionalnych trybunałów administracyjnych;

— przygotowanie założeń do raportu rocznego sporządzanego przez Prezesa Rady Ministrów do Parlamentu na temat stanu administracji sądowej;

- ustanawianie ogólnych kryteriów podziału i przyznawania spraw o charakterze opiniodawczym (konsultacyjnym) i odwołań od orzeczeń TAR — odpowiednio do sekcji doradczych (to jest sekcja I-III) i sądowych (sekcja IV-VI) Rady Stanu;

- ustanawianie ogólnych kryteriów rozdziału odwołań wnoszonych do sądów administracyjnych z podziałem na właściwe sekcje.

PRSA może ponadto przeprowadzać kontrolę w sekretariacie głównym Rady Stanu oraz w regionalnych trybunałach administracyjnych, powierzając przy tym to zadanie jednemu z jego członków ${ }^{24}$.

Prezydium Rady Sądownictwa Administracyjnego podejmuje także uchwały, o których mowa w art. 13 ust. 2 ustawy nr 186, dotyczące statusu sędziów sądów administracyjnych i obejmujące takie sprawy, jak zatrudnienie, przydział, przenoszenie czy awanse sędziów. Kompetencje PRSA w tym zakresie są zbieżne z kompetencjami NRS w odniesieniu do sędziów sądów powszechnych. Mimo iż NRS jest instytucją zakotwiczoną w Konstytucji Włoch w art. 104, nie oznacza to, że rola PRSA jest drugorzędna. W świetle art. 103 w związku z art. 113 ustawy zasadniczej Włoch sądowa ochrona praw i uzasadnionych interesów jednostek przed aktami administracji publicznej realizowana jest przez sądy powszechne i administracyjne, przy czym spory dotyczące administracji publicznej rozpoznaje Rada Stanu i organy sądownictwa administracyjnego. Oznacza to, że wprawdzie ustrojodawca nie wymienił wprost w Konstytucji organu, jakim jest PRSA, ale odesłał w tym zakresie do ustawodawstwa zwykłego. Dodatkowo liczne nowelizacje ustawy nr 186 oraz odesłania do aktów normatywnych regulujących zasady działania Najwyższej Rady Sądownictwa potwierdzają pozycję ustrojową Rady w odniesieniu do sędziów sądów administracyjnych, zrównując ją z pozycją NRS.

W świetle art. 104 ust. 1 Konstytucji Włoch sądy powszechne i administracyjne stanowią system autonomiczny i niezależny od innych władz, a sędziowie

24 Wskazane powyższe zostały rozszerzone w związku z nowelizacją ustawy z 21 lipca 2000 roku (ustawa nr 205), polegającą na dodaniu w art. 13 ust. 1 pkt 6 bis, zgodnie z którym Prezydium Rady Sądownictwa Administracyjnego określa kryteria i metody ustalania obciążeń sędziów. 
są niezawiśli, nieusuwalni i podlegają jedynie ustawom. Zasadniczym gwarantem tak określonej pozycji ustrojowej sądownictwa administracyjnego jest PRSA, które podejmuje uchwały w sprawach dotyczących rekrutacji kandydatów do urzędu sędziowskiego w ramach sądownictwa administracyjnego, w sprawach przydziałów bądź zmiany siedziby sędziów oraz ich funkcji, decyzji o przeniesieniu sędziów, awansów sędziów, przyznania sędziom funkcji kierowniczych i wszelkich innych postanowień dotyczących statusu prawnego sędziów.

Zgodnie z art. 13 ust. 2 ustawy kompetencje Rady dotyczące statusu sędziów sądownictwa administracyjnego wiążą się ponadto z podejmowaniem uchwał w następujących sprawach:

— środków dyscyplinarnych wobec sędziów;

— przyznawania sędziom zadań niezwiązanych z ich funkcjami, w celu zapewnienia sprawiedliwego podziału zarówno obowiązków, jak i wynagradzania;

— dotyczących kadry pracowników sądowych regionalnych trybunałów administracyjnych oraz w sprawie ewentualnego podziału na sekcje samych trybunałów;

- odstąpienia, w wyjątkowych przypadkach i z uzasadnionych przyczyn, od obowiązku przestrzegania rezydencji sędziego, o którym mowa w artykule 26 ustawy, pod warunkiem że przeniesienie ze stanowiska nie zostało dokonane na żądanie sędziego;

- dotyczących kadry pracowników sekretariatu i personelu pomocniczego Rady Stanu oraz regionalnych trybunałów administracyjnych;

— kryteriów tworzenia komisji specjalnych działających w Radzie, zgodnie z jej regulaminem wewnętrznym, a także we wszystkich innych sprawach określonych w ustawie.

Do ustawowych zadań Rady należy również rozpatrywanie wniosków o przeniesienie sędziego w stan spoczynku, rozpatrywanie wystąpień sędziów w stanie spoczynku o powrót na stanowisko sędziowskie, wybieranie rzecznika dyscyplinarnego

Rada ponadto w ramach swoich kompetencji:

- uchwala regulamin w ramach autonomii finansowej i regulamin wewnętrzny dotyczący organizacji biur sądownictwa administracyjnego, zgodnie $\mathrm{z}$ art. 53a ust. 2 ustawy z dnia 27 kwietnia 1982 roku nr 186;

— zatwierdza budżet organów sądownictwa administracyjnego;

— w razie potrzeby wyraża opinie na temat projektów ustaw lub wniosków ustawowych, lub innych aktów normatywnych dotyczących sądownictwa administracyjnego,

Do zadań Rady należą też inne sprawy związane z jej kompetencjami wynikające z przepisów ustawowych lub wykonawczych, lub przekazane do prac przez Przewodniczącego PRSA.

Kompetencje Rady świadczą o silnej pozycji ustrojowej sądownictwa administracyjnego, mimo że nie wynikają one wprost z Konstytucji Włoch, jak ma to miejsce w wypadku NRS w odniesieniu do sądownictwa powszechnego. Prze- 
mawia jednak za tym długa tradycja funkcjonowania sądów administracyjnych, sięgająca XIX wieku. Samorządność sędziów, przejawiająca się w decydowaniu o powołaniu sędziów, przez wpływ na ich status prawny po opiniowanie projektów aktów prawnych dotyczących funkcjonowania sądownictwa administracyjnego ma istotne znaczenie dla zagwarantowania każdemu konstytucyjnego prawa o sądu, co wynika z art. 24 ust. 1 Konstytucji Włoch.

\subsection{ZASADY DZIAŁANIA RADY}

Zasady organizacji i szczegółowy tryb działania Prezydium Rady Sądownictwa Administracyjnego określa regulamin wewnętrzny Rady z 2004 roku ${ }^{25}$. Zapewnia on właściwą organizację Rady, niezbędną do wykonywania przez nią swoich funkcji. W ramach struktury wewnętrznej działa biuro Rady (il Ufficio del Consiglio di Presidenza), na którego czele stoi sekretarz PRSA mianowany przez Radę na wniosek jej Przewodniczącego spośród sędziów sądów administracyjnych mąjących kwalifikacje na sędziego TAR. Powołanie sekretarza następuje bezpośrednio po posiedzeniu Rady, zgodnie z zasadą, że zostaje nim sędzia, który uzyskał większość co najmniej czterech piątych głosów członków Rady. Sekretarz pozostaje na stanowisku przez cały czas trwania kadencji Rady. W wypadku nieobecności sekretarza zastępuje go najstarszy funkcją sędzia — członek PRSA.

Przewodniczący PRSA zwołuje i przewodniczy posiedzeniom Rady oraz wykonuje wszystkie inne funkcje wynikające z przypisów prawa. W wykonywaniu swoich obowiązków pomaga mu biuro Rady. W wypadku nieobecności Przewodniczącego lub jego absencji spowodowanej inną przeszkodą posiedzenia Rady zwołuje wiceprzewodniczący. Rada zwoływana może być również na wniosek co najmniej 1/3 członków, w ciągu dwudziestu dni od złożenia wniosku ${ }^{26}$.

Zgodnie z art. 22 regulaminu wewnętrznego PRSA dzieli się na komisje stałe (Le Commissioni permanenti) i komisje specjalne (Le Commissioni speciali). Art. 23 regulaminu wewnętrznego przewiduje, w ciągu piętnastu dni od ukonstytuowania się Rady, utworzenie czterech stałych komisji właściwych w następujących dziedzinach: 1. komisja do określonych spraw związanych z kontrolą działalności sądownictwa administracyjnego (sprawowanie nadzoru nad działalnością sądów administracyjnych i sędziów), 2. komisja dotycząca postępowań dyscyplinarnych wobec sędziów; 3. komisja dotycząca organizacji i zasad funkcjonowania Rady

25 Regulamin wewnętrzny Prezydium Rady Sądownictwa Administracyjnego uchwalony 6 lutego 2004 roku (G.U. z 13 lutego 2004 r. Nr 36).

26 Porządek obrad jest przekazywany wszystkim członkom co najmniej siedem dni przed posiedzeniem. Dokumenty niezbędne do omówienia porządku obrad muszą być dostępne dla członków w tym samym terminie, w formie elektronicznej lub, na wniosek zainteresowanego członka, w formie papierowej w siedzibie Rady. W nagłych przypadkach zwołanie i porządek obrad muszą zostać podane do wiadomości co najmniej trzy dni przed posiedzeniem. Zasadniczo porządek obrad zawiera tematy już zbadane przez właściwe komisje (stałe lub specjalne). Rada zwykle podejmuje uchwały na podstawie przedstawionych propozycji przygotowanych przez właściwą komisję. 
Stanu oraz TAR; 4. komisja dotycząca statusu prawnego i ekonomicznego sędziów, w tym między innymi zasady awansów sędziowskich, zasady przydzielania funkcji. Każda Komisja podczas pierwszego posiedzenia wybiera ze swojego grona Przewodniczącego. Komisje specjalne natomiast mogą zostać powołane do rozpatrywania konkretnych spraw, wskazanych w uchwale je konstytuujących. Rada może również tworzyć grupy robocze (i gruppi di lavoro) mające na celu zebranie wstępnych informacji na temat spraw mieszczących się w ramach swoich kompetencji ${ }^{27}$. Uczestnictwo członków Rady w komisjach specjalnych i grupach roboczych podlega tym samym zasadom i traktowane jest tak samo jak w uczestnictwo w komisjach stałych.

Wszyscy członkowie Rady muszą być członkami przynajmniej jednej Komisji stałej. Zasadą jest, że wszyscy członkowie Rady mają prawo uczestniczyć w każdej komisji, z prawem do zabrania głosu. Jednakże prawo do głosowania podczas prac komisji mają tylko jej członkowie.

\section{PODSUMOWANIE}

Występowanie jednoczesne dwóch organów gwarantujących niezależność sądów i niezawisłość sędziów nie jest spotykane w porządkach konstytucyjnych państw. Republika Włoska jest więc w tym zakresie wyjątkiem. Świadczy to o bardzo silnej pozycji ustrojowej sądownictwa zarówno powszechnego, na której straży stoi Najwyższa Rada Sądownictwa, mająca swoje zakotwiczenie w Konstytucji Włoch, jak i sądownictwa administracyjnego, gwarantowaną przez Prezydium Rady Sądownictwa Administracyjnego. Mimo odmiennego składu obu organów każdy z nich zapewnia właściwą reprezentację sędziów odpowiednio sądów powszechnych i administracyjnych. Przy wyłanianiu członków realizowana jest bowiem podstawowa zasada - wyboru sędziów przez sędziów. Tym, co oprócz składu gwarantuje samorządność środowiska sędziowskiego, są kompetencje Najwyższej Rady Sądownictwa oraz Prezydium Rady Sądownictwa Administracyjnego, które dotyczą wszelkich spraw związanych z wykonywaniem funkcji sędziego. Ma to fundamentalne znaczenie dla zapewnienia autonomii i niezależności sądownictwa od pozostałych władz. Tylko bowiem tak ukształtowane sądownictwo może zagwarantować każdemu prawo do rozpatrywania jego sprawy przez niezawisły i bezstronny sąd.

27 Skład komisji specjalnych i grup roboczych ustala się zgodnie z uchwałą, która je ustanawia. Ta sama uchwała określa również czas trwania tych organów, który może zostać wydłużony odrębną uchwałą. 
THE PRESIDIUM OF THE ADMINISTRATIVE JUDICIARY COUNCIL AS THE ORGAN OF THE ADMINISTRATIVE JUDICIARY IN ITALY

\section{Summary}

In the legal system of the Italian Republic, there are two judicial self-government organs, which guarantee the independence of the courts and the independence of judges. The Supreme Judicial Council safeguards the independence of the common judiciary and the Presidium of the Administrative Judiciary Council — administrative judiciary. Despite the different composition of those organs, each of them ensures proper representation of judges of common and administrative courts. The election of judges by judges is the basic principle for the selection of the new council members. In addition, the competences of the Supreme Judicial Council and the Presidium of the Administrative Judiciary Council, are fundamental for guaranteeing the independence of the judiciary from the other public organs.

Keywords: administrative judiciary, Council of State, Presidium of the Administrative Judiciary Council, independence of courts, independence of judges, judicial self-government

\section{BIBLIOGRAFIA}

Angeletti A., Le origini del sistema di giustizia amministrativa, [w:] Il nuovo processo amministrativo, red. R. Caranta, Bologna 2011.

Caringella F., L'evoluzione e i principia, [w:] Manuale di diritto processuale amministrativo, red. A. Cacciari, R. Cauteruccio, Roma 2009.

Manuale di giustizia amministrativa (Seconda edizione), Roma 2013.

Witkowski Z., System konstytucyjny Włoch, Warszawa 2000. 